\title{
Analysis of the performance of the brazilian intellectual property system: challenges and perspectives
}

Cleiton Rodrigues de Vasconcelos

Doutor em Ciência da Propriedade Intelectual (PPGPI/UFS). Professor do Departamento de Engenharia de Produção da Universidade Federal de Sergipe (UFS).

cleitongv@yahoo.com.br

Daniel Pereira da Silva

Doutor em Biotecnologia Industrial - FAENQUIL (atual EEL/USP). Professor nos Programas de Pós-Graduação em Ciência da Propriedade Intelectual (PPGPI/UFS) e Rede Nordeste de Biotecnologia (Renorbio/UFS).

silvadp@hotmail.com

Editor Científico: José Edson Lara

Organização Comitê Científico

Double Blind Review pelo SEER/OJS

Recebido em 07.11.2017

Aprovado em 23.03.2018 


\begin{abstract}
The protection of intellectual property (IP) is a crucial area to support the development process of any country, as it is in this context that the biggest strategic disputes are taking place. In recent years Brazil has developed some actions to achieve greater efficiency in the public IP management system, but are we on the right track? The present study seeks to present indications and points of concern regarding the performance of Brazil and to highlight the advances and challenges regarding the IP system, that can be used as a reference for future policies and actions. The methodological approach was structured based on a review in the literature, highlighting the scientific, economic and technological indicators on the development of IP and the main IP objects registered with the Brazilian national intellectual property body (INPI) in the period of 2013 to 2016, in the areas of patents, trademarks, industrial design, computer program, circuit topography, technology contracts and geographical indication.
\end{abstract}

Keywords: Intellectual Property; Performance Indicators; Brazil.

\title{
Análise do desempenho do sistema brasileiro de propriedade intelectual: desafios e perspectivas
}

Resumo

A proteção da propriedade intelectual (PI) se apresenta como uma área crucial para apoiar o processo de desenvolvimento de qualquer país, pois é neste contexto que as maiores disputas estratégicas estão ocorrendo. Nos últimos anos, o Brasil tem desenvolvido algumas ações para alcançar maior eficiência no sistema público de gestão de PI, mas será que estamos no caminho certo? O presente estudo procura apresentar indicações e pontos de interesse sobre o desempenho do Brasil e destacar os avanços e desafios em relação ao sistema de IP, que podem ser utilizados como referência para futuras políticas e ações. A abordagem metodológica foi estruturada com base em uma revisão na literatura, destacando os indicadores científico, econômico e tecnológico sobre o desenvolvimento de $\mathrm{PI}$ e os principais objetos de $\mathrm{PI}$ registrados junto ao órgão nacional de propriedade intelectual do Brasil (INPI) no período de 2013 a 2016, nas áreas de patentes, marcas, desenho industrial, programa de computadores, topografia de circuitos, contratos de tecnologia e indicação geográfica.

Palavras Chave: Propriedade Intelectual; Indicadores de desempenho; Brasil.

\section{Análisis del desempeño del sistema brasileño de propiedad intelectual: desafíos y perspectivas}




\section{Resumen}

La protección de la propiedad intelectual $(\mathrm{PI})$ se presenta como un área crucial para apoyar el proceso de desarrollo de cualquier país, pues es en este contexto que las mayores disputas estratégicas están ocurriendo. En los últimos años Brasil ha desarrollado algunas acciones para lograr mayor eficiencia en el sistema público de gestión de $\mathrm{Pl}$, pero ¿estamos en el camino correcto? El presente estudio busca presentar indicaciones y puntos de preocupación sobre el desempeño de Brasil y resaltar los avances y desafíos con respecto al sistema de PI, que pueden usarse como referencia para futuras políticas y acciones. El enfoque metodológico fue estructurado con base en una revisión en la literatura, destacando los indicadores científico, económico y tecnológico sobre el desarrollo de PI y los principales objetos de PI registrados junto al órgano nacional de propiedad intelectual de Brasil (INPI) en el período de 2013 a 2013 2016, en las áreas de patentes, marcas, diseño industrial, programa de computadoras, topografía de circuitos, contratos de tecnología e indicación geográfica.

Palabras Clave: Propiedad Intelectual; Indicadores de desempeño; Brasil.

\section{Introduction}

The intellectual property protection theme is crucial to support the development process of any country, given that it is in this context that the greatest strategic disputes are occurring through: the domain of proprietary technology and information, responsible for the generation of royalties, the exploitation of patents and trademarks, the reproduction of Artistic and literary works, and also for the protection of the genetic patrimony (Matias-Pereira, 2011).

The World Trade Organization (WTO), along with other global institutions, has emphasized the crucial role of Intellectual Property Rights (IPR) as a catalyst for innovation and economic and cultural development around the world (Hudson \& Minea, 2013).

Intellectual property is currently responsible for most of the value generated by modern companies, especially in the most dynamic segments, those referring to products differentiated by brands and other distinctions, design and technological or author content (INPI, 2009).

There are progressive efforts in Brazil to achieve greater efficiency in the public intellectual property management system, which recently has led to restructuring in research activities which can be checked at the following examples: growth of mergers and the size of organizations; improved coordination between research units and the 
introduction of managerial approaches in universities to strengthen autonomy, accountability and business-inspired operational models (INPI, 2016).

Considering its expressiveness for the development of economies, studies on the evaluation of Intellectual Property in a broader concept, are gaining more and more expressivity, aiming for greater dynamicity and increasing adhesion by the countries.

To the extent that Science Technology and Innovation (ST\&I) policies are in the hands of the public sector, it is noticeable that many demands, as a result of the interaction between global markets, cannot be fully satisfied, not to mention that the formulation of development policies commonly finds resistance and conflict of interest.

With the purpose of presenting the actions related to the policies of the Brazilian government regarding the intellectual property system, the present article highlighted aspects in the scientific, economic and technological fields, for example: the precariousness of basic professional training (not only for the generation of knowledge, but focused on the Social demands), excessive bureaucracy in the exchange of experiences between companies and Research and Technology Organizations (RTOs) (structure and excessively complex contracts), companies with low technological potential for the poor qualification of the employed workforce, especially in areas with technological potential.

The methodological approach evidenced the scientific, economic and technological indicators presented in the global scenario on the development of intellectual property (IP). In the scientific and economic aspects, emphasis was placed on the investment of national GDP by government sectors and private sector in research and development activities, compared to the Organization for Economic Cooperation and Development (OECD) projections, as well as the approach of national indicators to measure the degree of innovation of the country's companies (training of professionals in strategic areas, percentage of professionals working in companies, rate of innovation of companies, etc.). In the technological area, the main IP objects in the areas of patents, trademarks, industrial design, software, technology contracts, geographical indication and circuit topography were categorized in the period from 2013 to 2016, despite bureaucracy and increased piracy.

The recent governmental initiatives (MCTI, 2016) maintain that the economic growth of the country is a matter of State responsibility, but the private initiative must 
contribute in the research activities strengthening its technological qualification and its capacity of productive innovation, generating more value to its products, its technological or authorial content, its brand, consolidating its capacity for intellectual protection (DeNegri et al., 2008; Matias-Pereira, 2011).

\section{Dynamics of the Intellectual Property System: Strategies and their Relations}

Intellectual Property (IP), in a broader definition, refers to the results of the creation of the human intellect, of the individual's inventive capacity (knowledge, technology and popular/traditional knowledge), allowing people to gain recognition or some financial benefit, provided that it does not conflict with the freedom of third parties and the legal norms in force (MCTI, 2016).

The definition presented by the World Intellectual Property Organization (WIPO), an institution related to the United Nations Organization (UNO), which is constantly updating and proposing international standards for the protection of intellectual creations worldwide, sets out a list of various objects that can be protected by intellectual property rights, such as: Literary, Artistic and scientific works (copyright); artistic interpretations, phonograms and broadcasting (related rights); inventions in various fields of human knowledge scientific discoveries, industrial design, trademarks, trade names and denominations, protection against unfair competition (industrial property).

According to WIPO, there are several reasons to promote a culture of intellectual property protection:

$\circ$ Reward for creativity and human effort;

- Promoting the progress and well-being of humanity by creating new forms of work in technological and cultural areas;

- The protection creates incentive for new creations, promoting innovation and resources to its financing;

- Stimulus to economic growth, making public information valuable and about new products and research;

- Without protection, consumers would not have the confidence to acquire new products, services or processes (legal actions against counterfeits), which are protected by brand characteristics (credibility, trust, quality).

The importance of Intellectual Property was first recognized in the Paris Convention for the Protection of Industrial Property (1883) and the Berne Convention for the Protection of Literary Works and Artistic Works (1886), both of which were administered by WIPO. 
The plurality of technological innovations associated with the end of the Second World War led to the development of new knowledge in areas such as telecommunications, energy and biotechnology. The expansion of the companies in a globalized scope began to require a restructuring in their process flows, market strategies, investments in research, with emphasis on the industrial property system. With the increase in the share of new product $R \& D$ expenditures, patents became an important factor in calculating the private rate of return on investment. Technology, therefore, becomes a prime factor in quantifying the competitive advantages of world markets (Cavalheiro, Joia, \& Veenstra, 2016).

The guarantees granted through IPRs became of great strategic importance among the different industrial segments, positively affecting the process of economic growth and technological progress of the countries in international trade.

Without the rewards provided by the IP system (brand protection mechanisms, counterfeiting and piracy), researchers and inventors would have little incentive to upgrade their products to consumers, and consumers would not have the confidence to purchase products or services without a registration or widely known certification (Hudson \& Minea, 2013). At some point, incentives for new inventions are offset by the costs of monopoly over existing technologies and the complexity of the invention, such as the case of the pharmaceutical and chemical industry (Deardorff, 1992; Donoso, 2017).

Some researches (Forero-Pineda, 2006; Tanaka \& Iwaisako, 2014; Brüggemann, Crosetto, Meub, \& Bizer, 2016), emphasize that IPRs have dynamic and static effects depending on the degree of the development of countries. Dynamic effects arise from the promotion of innovation, resulting in products of superior quality over time, providing well-being to consumers. On the other hand, static effects can be reflected in the strength of IPR protection, reducing the frequency of innovation of firms (especially for sectors characterized by a strong frequency in innovation processes) through the monopolistic effects of patents and affecting consumer welfare through the payment of fees and licenses, which are more noticeable in developing countries.

Forero-Pineda (2006), stresses that developed countries have exerted influence on developing countries towards a stronger position in intellectual property, covering both legislation and enforcement, thereby reducing the counterfeiting of firms with low 
technological capacity. Studies as such as Jandhyala (2015) and Cavalheiro, Joia and Veenstra, (2016), address how global and local pressures can influence the performance of IP policies and even protect domestic producers from external competition.

According to the United Nations Educational, Scientific and Cultural Organization (UNESCO, 2015), global economic growth or the sustainability of a country, should focus primarily on investments in science, technology and innovation (ST\&I) signalling that national development strategies must make better use of the power of science, especially in the most urgent global challenges.

\section{Brazilian Perspective Analyses Toward Intellectual Property}

The IP is currently responsible for most of the value generated by modern companies, especially in the most dynamic segments, those referring to products differentiated by brands and other distinctive features, design and technological or author content (INPI, 2009).

In Brazil, following the international trend, investments in infrastructure, expansion of education and research networks, partnerships between public and private agents, international cooperation, techniques that meet social demands, as well as the development of articulations and initiatives are some of the measures priorities to strengthen and expand ST\&I (MCTI, 2016).

The recent global economic crisis has particularly affected private investment in RD\&I, prompting governments to increase financial contributions to offset the downturn left by companies. However, the limitation in the public budget has led public agents to better evaluate their actions and allocations of their resources in strategic areas, especially those focused on energy, aerospace, health, water crisis, public security, national defense and the Amazon. However, evaluations on the impact of these incentives still present a major challenge for national governments (Matias-Pereira, 2011).

According to the UNESCO Science Report - Towards 2030 (2015), between 2004 to 2012, Brazil recorded the highest GDP investment rates in R\&D activities, and in 2012 ( $\$ 35.5$ billions) almost double that of 2004 (\$18, 5 billions). Since 2010, only the government sector has been increasing the intensity of R\&D investment, with the 
contribution of the private initiative shrinking from $0.57 \%$ (2010) to $0.52 \%$ (2012) of GDP. The projection for the coming years should follow this trend until the economy shows signs of recovery, which for the most optimistic analysts should not occur before 2016.

The intensive use of ST\&I in an economy allows the expansion of a nation's productive capacity, the creation of new enterprises, the attraction of investments, the generation of jobs, and competitive know-how with direct impacts on society.

The Table 1 shows the position of Brazil in relation to other economies, the percentage of GDP invested in $R \& D$ in 2012, as well as the contribution of governmental and business initiatives in this scenario.

\section{Table1}

Brazil's position on GDP R\&D investments in 2012 (\%)

\begin{tabular}{lcc}
\hline \multirow{2}{*}{ Countries } & \multicolumn{2}{c}{ Resource Sharing (\%) } \\
\cline { 2 - 3 } Korea & Public Resources & Private Resources \\
Germany & 0,96 & 3,07 \\
USA & 0,84 & 2,04 \\
France & 0,80 & 1,90 \\
Russia & 0,78 & 1,45 \\
Brazil & 0,76 & 0,36 \\
Canada & 0,63 & 0,52 \\
Portugal & 0,59 & 1,12 \\
India & 0,59 & 0,79 \\
Japan & 0,58 & 0,30 \\
Spain & 0,56 & 2,78 \\
Italy & 0,55 & 0,72 \\
United Kingdom & 0,54 & 0,73 \\
Argentina & 0,47 & 1,16 \\
China & 0,43 & 0,15 \\
South Africa & 0,43 & 1,55 \\
Mexico & 0,33 & 0,40 \\
\hline & 0,30 & 0,13 \\
\hline SSCO & & \\
\hline
\end{tabular}

Source: UNESCO (2015), INPI (2016)

Brazil remains well below the advanced economies (if compared with Korea, Japan and the United States) and emerging markets like China. It is also important to say that much surprising is the level of investment of the business sector in relation to the public sector if compared to these countries. It should be noted that, in relation to 
the BRICS economic bloc (Brazil, Russia, India, China and South Africa), Brazil ranks second among these countries and ahead of the majority in Latin America.

In recent years, government policy has maintained that the country's economic growth is a matter of State responsibility in priority areas as such as ST\&I, contributing to public and private actors working together for productive innovation (DeNegri et al., 2008; Matias-Pereira, 2011; MCTI, 2016). 63\% of the investments applied in R\&D in Brazil originated from the public sector and $37 \%$ from the private sector (UNESCO, 2015).

According to Matias-Pereira (2011), this strategy, in turn, tends to increase the interaction between industrial and technological policy and IP. In this sense, the management of public IP protection policies is an important instrument to support the economic growth of the country, but when there are deficiencies in the management of these policies their effects tend to affect the competitiveness of companies.

Considering that the construction of the IP culture involves the articulation of several agents in the process of economic development, Figure 1 presents the interaction of the various agents and their reflexes for the strengthening of the national IP system.

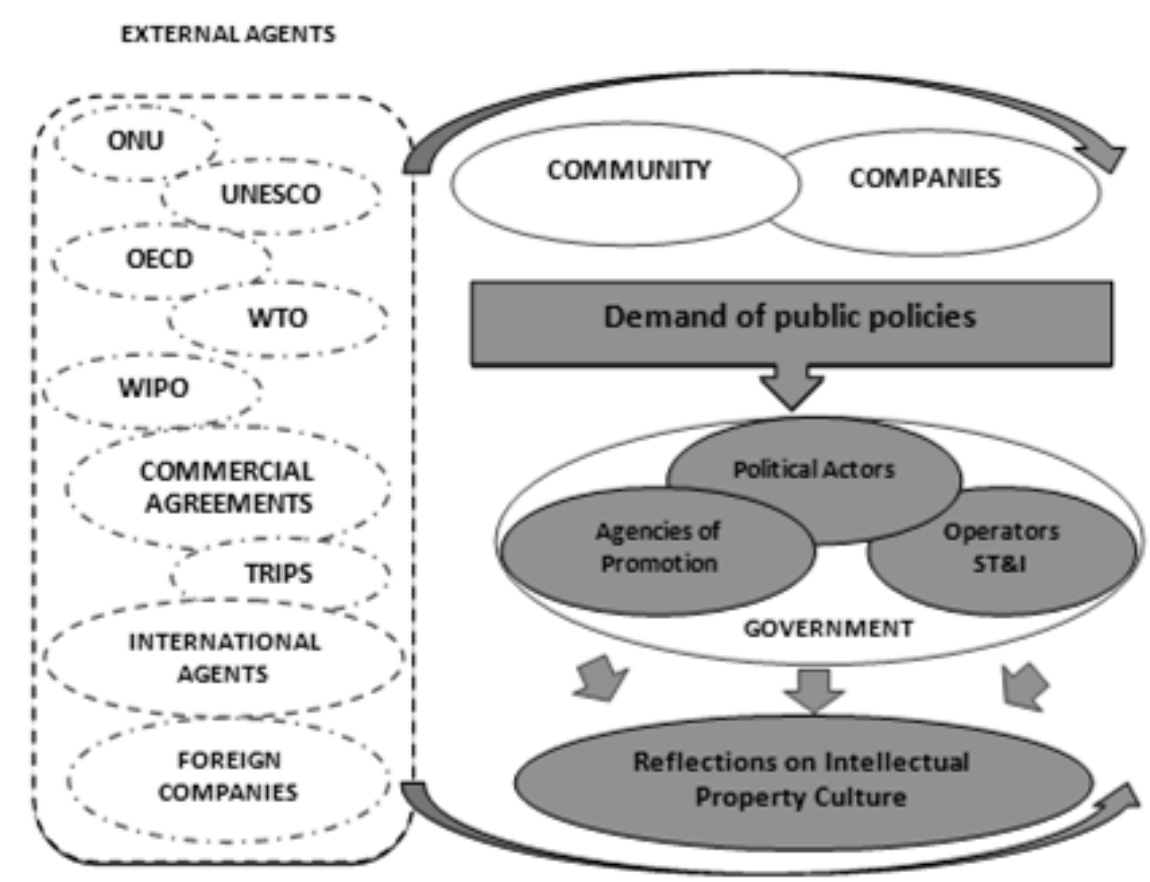

\section{Figure 1}

Chain of articulators of economic development of the country Source: Prepared by the authors. 
In Brazil, the year 1980 marked the creation of the Core of Technological Innovation (in portuguese Núcleo de Inovação Tecnológica -NIT), the first initiative of the government to stimulate the transfer of knowledge from universities to companies. Only with the Innovation Law (Lei n.10.973, 2004) is that there were a greater emphasis on the management of intellectual property with the objective of contributing to innovation, strengthening the specialized nuclei in intellectual property management (NIT), present at universities, and other Research and Technology Organizations (RTOs) measuring the scientific and technological production as well as the legitimacy of the interactions between companies and the RTOs as a strategy to strengthen scientific research in the organizational environment (Santos et al., 2009).

It should be noted that the IPR registration capacity of countries (especially patent concessions), scientific publications, collaboration between universities and companies (U-C), public and private investments in R\&D and the involvement of companies in R\&D, are important indicators of the level of development of a country (UNESCO, 2015; INPI, 2016).

\section{Evaluation of IP Management in Brazil: Scientific, Economic and Technological Indicators}

The National Institute of Industrial Property (in portuguese Instituto Nacional de Propriedade Industrial - INPI) is the Brazilian governmental institution, responsible for the improvement, dissemination and management of the Brazilian system of granting and guaranteeing intellectual property rights for the industry.

The INPI has become essential in supporting the creation of business value in a world in which intangible resources, as such as intellectual property, have become commercially more valuable and the target of economic-commercial conflicts, with the objective of complying with the international treaties related to Trade (TRIPS) and the treaties administered by WIPO and the fulfilment of national law (Cavalheiro, Joia, \& Veenstra, 2016).

The Figure 2 shows the distribution of the various objects that can be granted IPR in the Brazil. 
Figure 2

Structure of the objects of intellectual property protection in Brazil Source: Adapted from Jungmann \& Bonetti (2010) \& INPI (2016).

\section{Trademark}

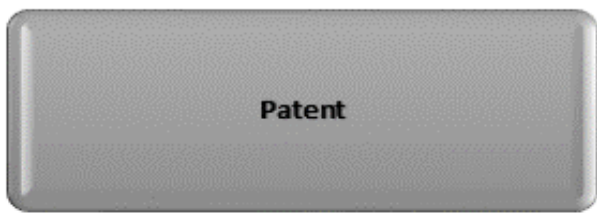

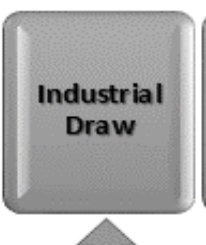

Product A

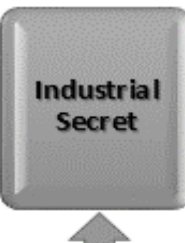

Product B

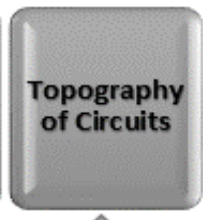

Product C
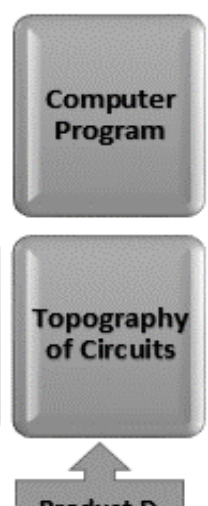
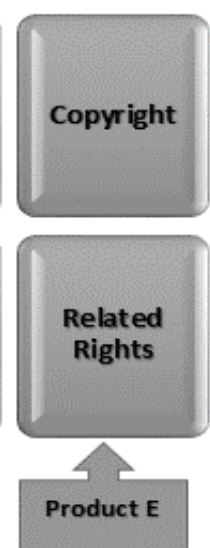

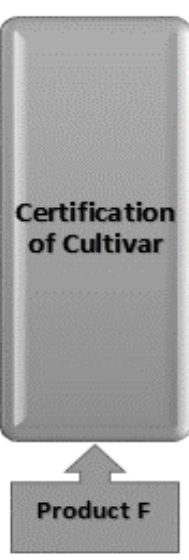

According to the Figure 2, various types of protection and different strategies can be granted to the same object as an example the industrial design of a new product, which may also be patentable and associated with the registration of a brand in the market (Product A); or the computer program or integrated circuit (Product B); certificate of new pest-resistant cultivars (Product F), etc. 
In a recent OECD study (Dernis et al., 2015) investigating more than 2,000 people involved in $\mathrm{R} \& \mathrm{D}$ worldwide have confirmed a strong complementarity between patent applications and trademark registration.

In accordance with Brazilian law, the various intellectual property objects may be classified in three broad areas: Industrial Property, Copyright and Protection "Sui Generis" (Figure 3), where, for each request, the intellectual property rights in Brazil, grants different deadlines depending on the characteristics of the "object".

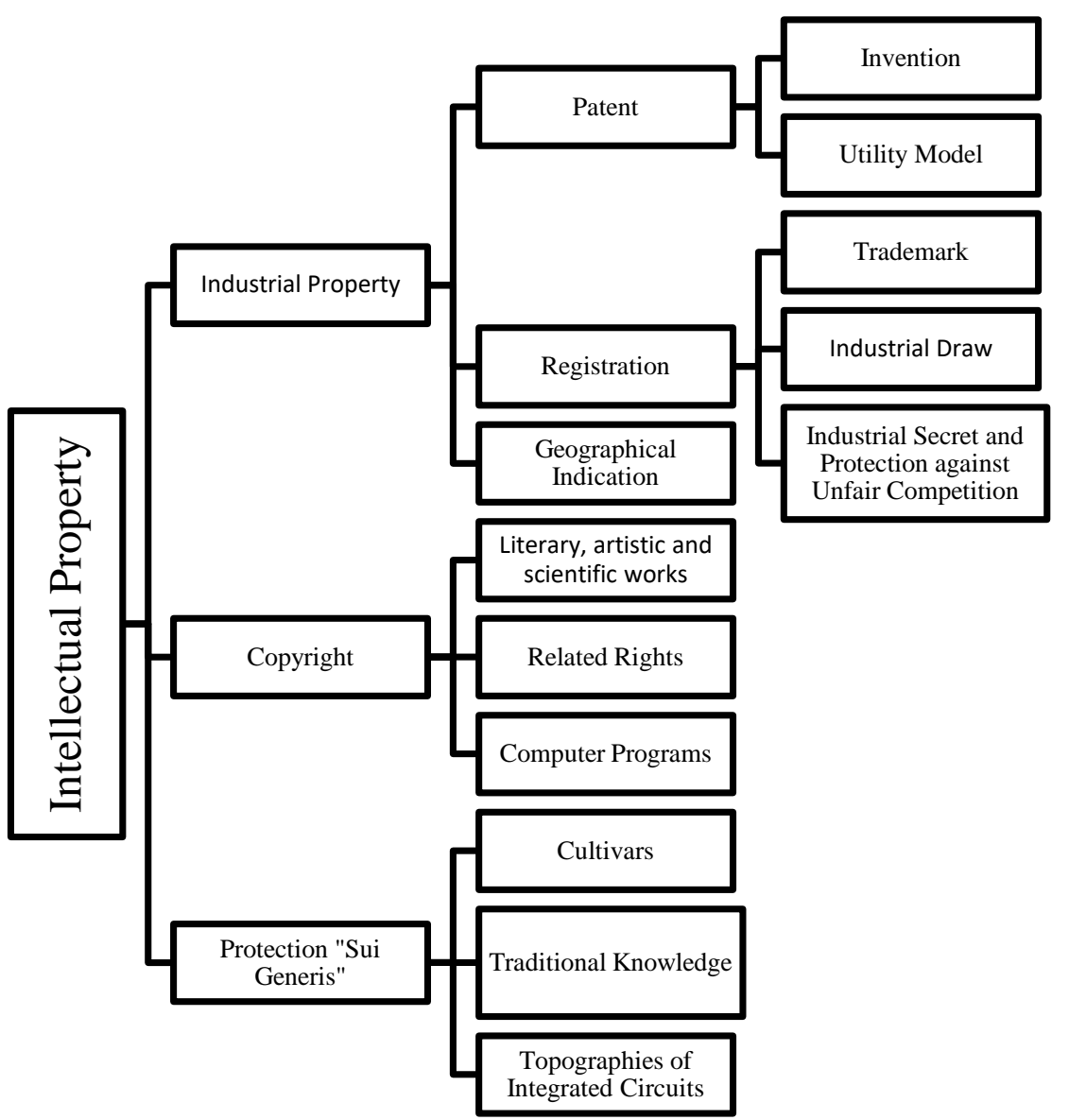

Figura 3

Protection of produtcs by different combinations of IPRs Source: Adapted from Jungmann \& Bonetti (2010).

Thus, companies can increase the visibility of their products, identify their brand, optimize the value of these goods, have barriers against competition, through secrecy or industrial design, monopoly in certain markets (in the case of the pharmaceutical industry), stimulate new production methods according to new emerging technologies, among other possibilities legally protected by intellectual property. 
INPI's operations in Brazil until the end of 2017 (INPI, 2017) registered about $44 \%$ of its offices without effective operation, impacting the lack of representation in some regions of the country, especially those with low intellectual property records in general, reflecting the quality of the services offered by agencies and their representative offices (Matias-Pereira, 2011). This situation reflects delays in the granting of registrations due to the low number of examiners, the accumulation of patent applications, potentially in new areas (nanotechnology, renewable energies, biotechnology), which demand greater knowledge, greater complexity of applications, issuance of dubious patents, discouraging the culture of intellectual property in the country.

The evidence of this INPI actions regarding the intellectual property system's initiatives concerning agility in the analysis of patent applications, new international treaties that bureaucracy processes, legislation that contemplate the diversities of IP policy, partnerships with other institutions, among other provisions.

\subsection{Scientific indicators}

Despite the efforts of the national IPR policy, the country has not yet expressed satisfactory results when comparing to other countries. According to UNESCO (2015), the justification involves a set of factors that includes the precariousness of basic vocational training (not only for the generation of knowledge, but focused on social demands), excessive bureaucracy in the exchange of experiences between companies and RTOs (structure and overly complex contracts), companies with low technological potential, low human resources training, especially doctors, who could be working in companies / industries in strategic areas such as power generation, health, technology, and a precarious infrastructure.

Regarding the participation of doctors researchers, Brazil has more than $60 \%$ working in universities, followed by companies and a smaller portion performing activities in the government. It is noteworthy that the researchers with a doctoral degree in business from 2001 to 2010 shrank 13.6\%, when comparing to other economies as listed: Korea, the United States, China and Mexico, which increased the participation of these professionals in their structures (Table 2). 


\section{Table 2}

FTE researchers in Brazil by sector, 2001 and 2011 (\%)

\begin{tabular}{ccccc}
\hline Countries & Period & Business (\%) & Government (\%) & Higher Education (\%) \\
\hline \multirow{2}{*}{ Argentina } & 2001 & 11,90 & 36,80 & 49,50 \\
& 2011 & 8,80 & 44,80 & 45,20 \\
\hline \multirow{2}{*}{ South Africa } & 2001 & 20,80 & 15,00 & 62,70 \\
& 2011 & 22,10 & 13,10 & 63,80 \\
\hline \multirow{2}{*}{ Brazil } & 2001 & 39,50 & 6,00 & 53,80 \\
& 2011 & 25,90 & 5,50 & 67,80 \\
\hline \multirow{2}{*}{ Spain } & 2001 & 23,70 & 16,70 & 58,60 \\
& 2011 & 34,50 & 17,60 & 47,70 \\
\hline \multirow{2}{*}{ Mexico } & 2001 & 17,40 & 30,30 & 50,40 \\
& 2011 & 41,10 & 19,80 & 38,80 \\
\hline Russian & 2001 & 56,10 & 28,60 & 14,80 \\
Federation & 2011 & 48,00 & 31,60 & 20,10 \\
\hline \multirow{2}{*}{ China } & 2001 & 52,30 & 25,10 & 22,60 \\
& 2011 & 62,10 & 19,00 & 18,90 \\
\hline \multirow{2}{*}{ USA } & 2001 & 60,00 & 4,80 & 35,20 \\
& 2011 & 68,10 & 3,30 & 28,60 \\
\hline \multirow{2}{*}{ Republica of } & 2001 & 73,50 & 8,80 & 16,90 \\
Korea & 2011 & 77,40 & 7,30 & 14,10 \\
\hline \multirow{2}{*}{ 2010 } & & &
\end{tabular}

Source: Adapted from OECD (2014); UNESCO (2015).

In Brazil, it is in the universities that most of the country research is carried out, especially in the public ones, which means that the teachers are responsible for a significant part of the national scientific production (MCTI, 2016). According to data from the National Council for Scientific and Technological Development (in portuguese Conselho Nacional de Desenvolvimento Científico e Tecnológico -CNPq) (2015), the contingent of researchers between 2010 and 2014 registered a growth of $39.9 \%$. Highlight should be given to the growth in the number of researchers with a PhD $(42.5 \%)$, which was higher than the growth of the total number of researchers, a fact that indicates the expansion of postgraduate programs and infrastructure in research, being the fulfilment of the demands of the productive sector is still incipient (UNESCO, 2015).

In the developed countries up to $80 \%$ of the researchers and their studies are located in the companies, while the remaining $20 \%$ are in the universities (MatiasPereira, 2011). It is worth noting that in the US case the RD\&I workforce profile is not made up of masters and doctors, about $15 \%$ of RD\&I staff have a PhD, while $27 \%$ 
have a master's degree and 55\% only graduate (MCTI, 2016), which evidences a technical formation with broad cooperation to the demands of technological development and innovation. In the Brazilian case, the low proportion of researchers working in companies could be one of the explanations for the poor performance in the main rankings of patent applications in the world (USPTO \& WIPO/PCT) (MatiasPereira, 2011).

The Table 3 shows the evolution of patents granted to Brazilian residents by the United States Patent and Trademark Office (USPTO), one of the world's leading IPR grant institutes.

\section{Table 3}

Invention patents granted to Brazilians by USPTO (2004-2008 and 2009-2013)

\begin{tabular}{|c|c|c|c|c|}
\hline Countries & $\begin{array}{l}\text { № of Patents, } \\
\text { 2004-2008 }\end{array}$ & $\begin{array}{c}\text { № of Patents, } \\
2009-2013\end{array}$ & $\begin{array}{l}\text { Cumulative } \\
\text { Growth (\%) }\end{array}$ & $\begin{array}{l}\text { Per } 10 \text { million inhabitants, } \\
2009-2013\end{array}$ \\
\hline Japan & 34048 & 45810 & 34,5 & 3592 \\
\hline USA & 86360 & 110683 & 28,2 & 3553 \\
\hline Korea & 3802 & 12095 & 218,1 & 2433 \\
\hline Sweden & 1561 & 1702 & 9,0 & 1802 \\
\hline Germany & 11000 & 12523 & 13,8 & 1535 \\
\hline Canada & 3451 & 5169 & 49,8 & 1499 \\
\hline Netherlands & 1312 & 1760 & 34,1 & 1055 \\
\hline United Kingdom & 3701 & 4556 & 23,1 & 725 \\
\hline France & 3829 & 4718 & 23,2 & 722 \\
\hline Italy & 1696 & 1930 & 13,8 & 319 \\
\hline Spain & 283 & 511 & 80,4 & 111 \\
\hline Chile & 13 & 34 & 160,0 & 33 \\
\hline China & 261 & 3610 & 1285,3 & 27 \\
\hline South Africa & 111 & 127 & 14,2 & 25 \\
\hline Russia & 198 & 303 & 53,1 & 21 \\
\hline Poland & 15 & 60 & 313,7 & 16 \\
\hline Argentina & 54 & 55 & 3,4 & 14 \\
\hline India & 253 & 1425 & 464,2 & 12 \\
\hline Brazil & 108 & 189 & 74,6 & 10 \\
\hline Mexico & 84 & 106 & 25,1 & 9 \\
\hline Turkey & 14 & 42 & 200,0 & 6 \\
\hline Global Average & 164835 & 228492 & 38,6 & 328 \\
\hline
\end{tabular}

Source: Adapted from UNESCO (2015); USPTO (2015).

Analysing the period highlighted (2004-2013), Brazil registered strong growth in absolute data. Compared with the countries of the BRICS economic bloc, Brazil is ahead of countries like Russia and South Africa in relation to the accumulated growth 
of patents in the period, but if we take into account the territorial extension / population, Brazil is less expressive, showing a low proportion among all the others countries. Countries as such as Japan and Korea with significantly similar regulations may present significant differences in the number of patents granted (Matias-Pereira, 2011; UNESCO, 2015).

It is worth noting that despite the growth in the number of patents in all highlighted countries, developed countries such as the USA, the European Union, Japan, South Korea and China are attracting most patent applications worldwide, in addition to the significant increase in applications for registration of trademarks and applications in industrial design between 2003 and 2013, with emphasis also on emerging economies such as India and Russia (Alcácer, Beukel, \& Cassiman, 2017).

The unfavourable situation of Brazil may not be measured only by looking at the number of patents granted, but it is a good indicator. As there is a delay in the granting of patents by the USPTO, the data record reflects what happened in past periods, being a parameter to analyse the countries among the possible effects of the IPR concession process, such as protectionist barriers, scientific cooperation and commercial, regulatory requirements, the country's competitive know-how, among others (MCTI, 2016).

Donoso (2017) emphasizes that the high country patent volumes do not reflect the differences in country legislation, and it is increasingly necessary to seek other indicators to understand RD\&I efforts. The mere addition of patents without any measure of the quality of the invention (e.g. inventive step covered by a patent) inflates the innovation measure for countries where most patents are only minor inventions of prior inventions. Likewise, the unweighted sum of patents ignores the sophistication and complexity of each innovation, and only assumes that all patents have the same innovative content and impact.

Nevertheless, levels of application of IP law vary dramatically between countries, criminal sanctions may not be imposed with the same severity, reducing the deterrent effects of such actions (Papageorgiadis, Alexiou, \& Nellis, 2016).

Another indicator that shows the country's scientific potential is the volume of publications in journals of great relevance in the world scenario, highlighting the most representative fields of research. According to Ministry of Science, Technology and 
Innovation (in Ministério da Ciência Tecnologia e Inovação -MCTI) (MCTI, 2016), Brazil between 2008-2014 demonstrated a significant growth in scientific diffusion, highlighting its publications in areas as such as: Health Sciences $(52,334)$; Biological Sciences (46,676); Agriculture (21,181); Physics (17,321); Chemistry (16,066); Engineering (14,278), among others; with the largest public investments in GDP.

In this scenario, actions should be encouraged to allow companies access to the competencies installed in Brazilian universities, creating cooperation environments in a broad spectrum, and in a more cohesive way among the regions, stimulating national development.

It is worth examining the structural differences between higher education systems, rather than simply transposing the law into the institutional environment. Much of the current literature discusses ways to make this U-C cooperation more efficient, the motivations, conflicts of interest and justifications of researchers who support these initiatives, whether through technology transfer offices or other informal relationships (Stal \& Fujino, 2016).

The studies of Stal and Fujino (2016) have shown that closer ties between the private and academic sectors need to be bridged and the barriers that have historically kept the business community away from the academic world. Actions ranging from bureaucratic culture change, institutionalization of partnerships, new collaborative licensing agreements for new technologies (such as patent pools and patent funds) that can converge with corporate interests. Situations that have been superseded by the relaxation of policies in the USA (Bayh-Dole Law') and inspired by several countries in Europe (Denmark, Germany, Austria, Norway, Finland, France, Switzerland, United Kingdom, among others).

Therefore, there is still a long way to go for cooperation between universities and companies (U-C) in Brazil, in the search for models to increase the level of innovation, since the country historically has no tradition in conducting R\&D.

\subsection{Economic indicators}

The economic policy of 1950, based on a strategy of importing technology and foreign capital, was not favourable to our national technological qualification in its products and processes. In an opposite way stimulated local companies to specialize 
in primary sectors and multinationals in high technology. Not to mention that the monopoly and oligopoly situations of the stronger economies prevented equitable access to technology (Forero-Pineda, 2006; Stal \& Fujino, 2016).

This situation reflects the structural imbalance in the export of basic commodities (mostly grains, iron ore, meats), together with the importation of products with high added value. Not discrediting the competitive advantages of mega biodiversity and the natural resources that the country has and the recent technological advances in the aeronautical, oil and gas and nuclear sectors (MCTI, 2016).

Brazil in general has a low level of exports, registering negative variations in 2012 $(4.74 \%)$ in $2016(-2.9 \%)$ in commodities and in relation to manufactured and semimanufactured products, the situation is much more critical (MCTI, 2016). Needing industrial and commercial policies that stimulate the country's diversification in world trade.

The MCTI for the period 2016-2019 highlights some of the indicators (Table 4) and more specific instruments for monitoring the planned initiatives and a reflection on the necessary adjustments in programs and plans that implement the guidelines outlined by ST\&I managers for decision making. If, on the one hand, there are recognized limitations of these indicators, which represent more the supply of resources than the results of the investments, on the other hand it reasonably synthesizes the relative positioning of the nation on the topic ST\&I (MCTI, 2016).

\section{Table 4}

Indicators used in the monitoring of the Brazilian Strategy for ST\&I

\begin{tabular}{clccc}
\hline \multicolumn{1}{c}{ Indicators } & $\begin{array}{c}\text { Last official date } \\
\text { and corresponding } \\
\text { year }\end{array}$ & $\begin{array}{c}\text { Projection } \\
\text { for 2019 }\end{array}$ & Source \\
\hline 1 & $\begin{array}{l}\text { National expenditure on R D in } \\
\text { relation to GDP }\end{array}$ & $1,24 \%(2013)$ & $2 \%$ & $\mathrm{MCTI}$ \\
\hline 2 & $\begin{array}{l}\text { Business expenditures in R\&D relative } \\
\text { to GDP }\end{array}$ & $0,52 \%(2013)$ & $0,90 \%$ & $\mathrm{MCTI}$ \\
\hline 3 & $\begin{array}{l}\text { Government expenditures on R\&D } \\
\text { relative to GDP }\end{array}$ & $0,71 \%(2013)$ & $1,10 \%$ & $\mathrm{MCTI}$ \\
\hline 4 & $\begin{array}{l}\text { Federal government spending on } \\
\text { R\&D relative to GDP }\end{array}$ & $0,50 \%(2013)$ & $0,80 \%$ & $\mathrm{MCTI}$ \\
\hline 5 & $\begin{array}{l}\text { Rate of enterprise innovation } \\
\text { Number of companies doing }\end{array}$ & $35,7 \%(2011)$ & $48,6 \%$ & PINTEC \\
\hline 7 & $\begin{array}{l}\text { \% of innovative companies using at } \\
\text { least one of the different government }\end{array}$ & $34,2 \%(2011)$ & $40 \%$ & PINTEC \\
\hline
\end{tabular}


support tools for innovation in enterprises

\begin{tabular}{|c|c|c|c|c|}
\hline 8 & $\begin{array}{l}\text { Number of technicians and } \\
\text { researchers engaged in } R \& D \text { in } \\
\text { companies }\end{array}$ & $103.290(2011)$ & 120.000 & PINTEC \\
\hline 9 & $\begin{array}{l}\text { Percentage of graduates of } \\
\text { undergraduate courses in engineering } \\
\text { in relation to the total number of } \\
\text { undergraduates in all areas }\end{array}$ & $7,2 \%(2013)$ & $12 \%$ & INEPiii \\
\hline 10 & $\begin{array}{l}\text { Number of researchers per million } \\
\text { inhabitants }\end{array}$ & 709 (2010) & 2.100 & MCTI \\
\hline
\end{tabular}

NOTE: Data from the last PINTEC (technological innovation research) survey (2009-2011), published by IBGE in 2013 in its fifth edition.

Source: Adapted from INPI (2016); Russo et al., (2017).

Placing Brazil among the top countries in global ST\&I is a major challenge, which can be achieved only when there are significant advances in the Gross Domestic Product (GDP) in R\&D areas. The goal of investing 2\% of GDP in R\&D for 2019 (value that would bring Brazil to an investment level closer to the OECD average of 2.3\%) are key actions for the repositioning of Brazil among the most dynamic economies (UNESCO, 2015).

There is a strong tendency for government initiatives to be less generic and more specific, such as targeted support for technology-based start-ups, spin-offs or small and medium-sized enterprises (SME) rather than investing in an entire business community. In addition to tax incentives, and protectionist measures that end up affecting the competitiveness of companies internationally and the innovative potential (UNESCO, 2015).

With regards to the support for start-ups, special attention has been given to those who need faster analysis of their patent applications given the urgency of obtaining protection. Thus, some mechanisms to support patent applications have been adopted, such as the granting of subsidies and advisory services. The commercialization of patents has been stimulated by means of support services for the commercialization of patents by companies, universities and research institutes (MCTI, 2016). 


\subsection{Technology indicators}

According to the latest report released by INPI (2017) the period from 2013 to 2016 showed the following percentage variations among the services offered by the Institute (Table 5).

\section{Table 5}

Statistics of services provided by INPI, 2013-2016

\begin{tabular}{|c|c|c|c|c|c|}
\hline \multirow[b]{2}{*}{$\begin{array}{l}\text { Services - } \\
\text { INPI }\end{array}$} & \multicolumn{4}{|c|}{ Periods } & \multirow[b]{2}{*}{$\begin{array}{c}\text { Variation } \% \text { of } \\
\text { period, 2013-2016 }\end{array}$} \\
\hline & $\begin{array}{l}2 \\
0 \\
1 \\
3\end{array}$ & $\begin{array}{l}2 \\
0 \\
1 \\
4\end{array}$ & $\begin{array}{l}2 \\
0 \\
1 \\
5\end{array}$ & $\begin{array}{l}20 \\
16\end{array}$ & \\
\hline \begin{tabular}{l}
\multicolumn{1}{c}{ Patents } \\
(Includes: \\
Invention \\
Patent, Utility \\
Model and \\
Addition \\
Certificate)
\end{tabular} & $\begin{array}{l}3 \\
3 \\
4 \\
. \\
0 \\
5 \\
0\end{array}$ & $\begin{array}{l}3 \\
3 \\
1 \\
1 \\
8 \\
2\end{array}$ & $\begin{array}{l}0 \\
4 \\
3\end{array}$ & $\begin{array}{l}31 \\
.0 \\
20\end{array}$ & $-9,77 \%$ \\
\hline $\begin{array}{l}\text { Trademark } \\
\text { (Includes: } \\
\text { Products, } \\
\text { Services, } \\
\text { Collective and } \\
\text { Certification) }\end{array}$ & $\begin{array}{l}1 \\
6 \\
3\end{array}$ & $\begin{array}{l}1 \\
5 \\
7\end{array}$ & $\begin{array}{l}1 \\
5 \\
8 \\
\dot{7} \\
0 \\
9\end{array}$ & $\begin{array}{c}16 \\
6 . \\
36 \\
8\end{array}$ & $1,77 \%$ \\
\hline $\begin{array}{l}\text { Industrial } \\
\text { Draw }\end{array}$ & $\begin{array}{l}8 \\
4 \\
7 \\
\end{array}$ & $\begin{array}{l}5 \\
9 \\
0 \\
\end{array}$ & $\begin{array}{l}0 \\
3 \\
9 \\
\end{array}$ & $\begin{array}{c}6 . \\
02 \\
7\end{array}$ & $-13,61$ \\
\hline $\begin{array}{l}\text { Computer } \\
\text { Programs }\end{array}$ & $\begin{array}{l}5 \\
0 \\
8 \\
\end{array}$ & $\begin{array}{l}6 \\
0 \\
9 \\
\end{array}$ & $\begin{array}{l}6 \\
1 \\
6 \\
\end{array}$ & $\begin{array}{c}1 . \\
80 \\
2\end{array}$ & $16,32 \%$ \\
\hline $\begin{array}{l}\text { Technology } \\
\text { Contracts }\end{array}$ & $\begin{array}{l}1 \\
7 \\
2 \\
5\end{array}$ & $\begin{array}{l}7 \\
1 \\
0\end{array}$ & $\begin{array}{l}4 \\
0 \\
0\end{array}$ & $\begin{array}{c}1 . \\
02 \\
7\end{array}$ & $-68,00$ \\
\hline $\begin{array}{l}\text { Geographical } \\
\text { Indications }\end{array}$ & 6 & $\begin{array}{l}1 \\
2\end{array}$ & $\begin{array}{l}1 \\
2\end{array}$ & 5 & $-20 \%$ \\
\hline $\begin{array}{c}\text { Circuit } \\
\text { Topographies }\end{array}$ & 4 & 1 & 3 & 9 & $55,55 \%$ \\
\hline
\end{tabular}

Source: INPI (2017).

\footnotetext{
Source:INPI (2017).
} 
The years considered in Table 5 , only requests related to registration of trademarks, computer programs and circuit topographies increased with INPI, with technology contracts having the worst performance compared to other services offered by the Institute. In the last case, transactions not covered by industrial property rights (as such as contracts for the assignment and licensing of patents, industrial designs and trademarks, technical assistance and the provision of know-how, as well as business franchises), If the interested part wants to license their assets, or obtain a license to boost their business, thus ensuring a secure agreement and conferring validity before third parties (INPI, 2016).

The concerning technology contracts, companies with higher contract demands, as such as: Petrobras S.A, Embraer, Arcelormittal Brazil S.A., Vale S.A., Volkswagen of Brazil Motor Vehicle Industry Ltda., registered a decline in registrations from 2014, explained by the significant reductions in requests and partnerships with the market (INPI, 2016).

It is worth noting that the 2016 Olympic Games based in Brazil contributed to the growing registration of brands, especially the Organizing Committee of the 2016 Olympic Games and the Brazilian Olympic Committee, which from 2013 to 2015 registered 1,078 brands, representing only a part of the impact of the Olympic Games on trademark applications (INPI, 2016).

Despite growing worldwide piracy, and significant losses to the illegal market for computer programs (Jungmann \& Bonetti, 2010), Brazil still managed to accumulate a positive balance between 2013 and 2016, but according to the Monthly Bulletin of Intellectual Property (INPI, 2017), already at the beginning of 2017 these indexes tend to retraction.

One of the great challenges of products as such as software's, video films and music, is the difficulty in protecting oneself, when compared with the other industrial products, since the facility of copy is much greater (Jandhyala, 2015).

The international obligations and external pressures to protect authors' works have shown little practical effectiveness in newly industrialized countries as such as Asia and Latin America, and despite Brazil's participation in international agreements (TRIPS Agreement 1998), the country has neglected the application of these laws, resulting in more than half of the Brazilian market in pirated products. A decrease in 
the piracy rate implies, therefore, a better protection of intellectual property rights and the enrichment of the technological patrimony of society (Forrero-Pineda, 2006).

The negative impacts of counterfeiting and piracy are projected to drain $\$ 4.2$ trillion from the global economy and put 5.4 million legitimate jobs in risk by 2022 . Not to mention that counterfeit and pirated products endanger health and consumer security around the world, bypassing government revenues, reducing corporate profits and legitimate jobs. The International Chamber of Commerce (ICC) relies on the Business Action to Prevent Counterfeiting and Piracy (BASCAP), seeking government support to strengthen IP enforcement at the national, regional, multilateral and international levels, seeking G20 iv on concrete actions in their governments (ICC, 2016).

Among requests for IP rights, it is worth highlighting the relationship between residents and non-residents, as well as the form of origin of these deposits (Table 6).

\section{Table 6}

IP requests by depositor source and input media, 2013-2016

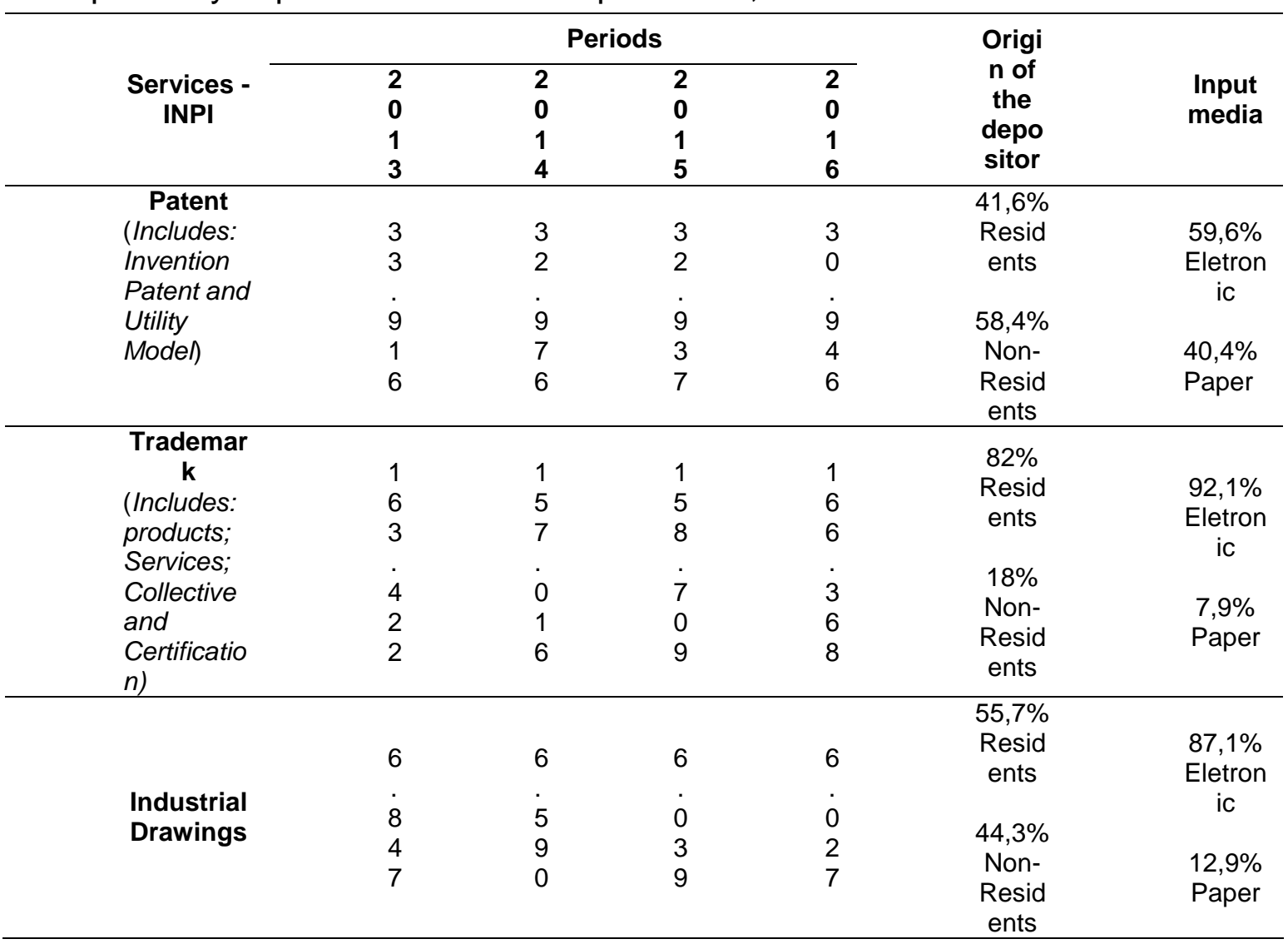

Source: Adapted from INPI (2016). 
From Table 6, it can be seen that the patent applications granted to NonResidents (including only patents and utility models) stand out (58.4\%), as well as among all the services analysed. Electronic media is the most used form considering all users (residents and non-residents) of the period.

Among the residents, the Southeast and South regions (with the states of Sao Paulo and Rio Grande do Sul, respectively, notable expressivity), has historically concentrated the largest volumes of IP applications, generally associated with Education, Research and Government (INPI, 2016).

Among the non-resident countries, USA, Germany, Japan, Sweden, France and Italy are the most prominent in patent and industrial design registrations (INPI, 2017).

The industrial design registrations, despite their downturn in the observed period $(-13.61 \%)$, had a good adhesion among the residents of the country, as well as the trademark certificates, with a large prevalence of medium and large companies in the requests for Trademark registrations (MCTI, 2016).

It is worth noting that the participation of corporate patents has increased its presence, mainly related to research within the limits of laboratories specialized in $R \& D$ and departments of companies, government and universities (Donoso, 2017).

In this sense, there is great scope to expand patent applications between residents and non-residents, given the volume of research and the tendency of the country to internationalize its assets. As well as the interest of other economies by the Brazilian market.

\section{Final Considerations and Perspectives}

The practical evaluation of intellectual property is a complex and difficult issue, as there are many factors that influence it, in addition to the different methodologies used by the countries and the enforcement of laws. Since countries have exclusions for some innovations and most inventive activities occur outside the patent system (Donoso, 2017).

In Brazil, the culture of Intellectual Property is still incipient, requiring a more efficient cohesion between the state's public policies, teaching and research 
institutions and companies, in order to produce science with the potential contribute to the country economic development.

It is worth emphasizing that the expansion of undergraduate and postgraduate courses should increasingly cooperate with the demands of the productive sector, increasing the proportion of researchers working in companies resulting in research that drives technological development and innovation. In this scenario, actions should be encouraged to allow companies to access the competencies installed in Brazilian universities, creating cooperation environments in a broad spectrum, and in a more cohesive way among the regions, stimulating national development. Actions ranging from bureaucratic culture change, institutionalization of partnerships, new collaborative licensing agreements for new technologies (such as patent pools and patent funds) that can converge with corporate interests.

As for the scientific potential, since 2008 Brazil has revealed a very significant potential regarding the number of publications, but considering the periodicals of greater relevance in a worldwide scenario, the numbers are still discrete, evidencing that often the work has reduced character of originality.

Thus, this situation should require fundamentally structural changes, rather than short-term actions, involving basic training of human resources in areas that meet social demands such as those for energy generation (renewable energy), health (biotechnology) and technologies (nanotechnology) with potential to be absorbed by the market. In addition to the cooperation between business and government, especially the latter in reducing bureaucracy, strengthening technology transfer and stimulating technology-based companies.

This situation should require fundamentally structural changes, rather than shortterm actions, involving basic training of human resources in areas that meet social demands such as those for energy generation (renewable energy), health (biotechnology) and technologies (nanotechnology) with potential to be absorbed by the market. In addition to the cooperation between business and government, especially the latter in reduction of bureaucracy in the broad sense, strengthening technology transfer and stimulating technology-based companies.

In this sense, the promotion of IP culture must go beyond the policies coordinated by the INPI, involving the academic community to cooperate with companies and 
society as a whole in solving their demands, a situation that has been adopted by several European countries in the sense to foster the economic importance of the intellectual property that is being developed in order to avoid that its projects with possibilities of commercial application are unduly divulged in the scientific environment without any previous strategy for future exploration.

It is worth emphasizing that the efforts of researchers and inventors to improve their products to consumers or some patentable industrial process can be rewarded by the costs of monopoly over existing technologies, brand protection mechanisms and anti-piracy in the IP system according to the degree of complexity of the invention.

\footnotetext{
'The Bayh-Dole Act (Public Law 96-517), passed in the United States in December 1980, introduced the motivation for profit directly into the heart of academic life, diverted teachers from curiosity-driven basic research, and favored the execution of projects Of research with immediate market potential amid worries about the country's loss of competitiveness. Technological capacity has become the main goal of industrial policy, for which cooperation with universities was essential (Thursby \& Thursby, 2011).

ii The PINTEC survey since the year 2000 has the objective of constructing national sector indicators and, in the case of industry, also regional, of the innovation activities of Brazilian companies, comparable with information from other countries. The focus of the research is on the factors that influence the innovative performance of the companies, the strategies adopted, the efforts undertaken, the incentives, the obstacles and the results of the innovation. Available at: http://www.pintec.ibge.gov.br/ (accessed 17 june 2016).

iiiThe INEP is a body linked to the Brazilian Ministry of Education focused on the formulation of educational policies, evaluation of basic and higher levels of teaching and other international educational actions. Available at: http://portal.inep.gov.br/conheca-o-inep (accessed 17 june 2016).

${ }^{\text {iv }}$ Created in 1999, the G20 is a kind of forum for cooperation and consultation on international financial affairs, bringing together 19 countries of the world's most developed economies, plus member countries of the European Union. Among the countries include South Africa, Germany, Saudi Arabia, Argentina, Australia, Brazil, Canada, China, South Korea, United States, France, India, Indonesia, Italy, Japan, Mexico, United Kingdom, Russia, Turkey.
}

\section{References}

Alcácer, J., Beukel, K., \& Cassiman, B. (2017). Capturing Value from Intellectual Property (IP) in a Global Environment. In Geography, Location, and Strategy (pp. 163-228). Emerald Publishing Limited.

Ávila, J. (2007, April). O INPI e a Propriedade Intelectual no Brasil: resultados e metas. Proceedings of the Congresso Brasileiro de Inovação na Indústria, São Paulo, Brazil, 2. 
Brüggemann, J., Crosetto, P., Meub, L., \& Bizer, K. (2016). Intellectual property rights hinder sequential innovation. Experimental evidence. Research Policy, 45, 20542068. https://doi.org/10.1016/j.respol.2016.07.008

Cavalheiro, G., Joia, L. A., \& Veenstra, A. (2016). Examining the trajectory of a standard for patent classification: An institutional account of a technical cooperation between EPO and USPTO. Technology in Society, 46, 10-17. https://doi.org/10.1016/j.techsoc.2016.04.004

Deardorff, A. (1992). Welfare effects of global patent protection. Economica, 59, 3551. https://doi.org/10.2307/2555064

DeNegri, J.A. (Ed.) n/a et al. (2008). Políticas de Incentivo à Inovação Tecnológica no Brasil. Brasília: Ipea. Retrieved from http://www.ipea.gov.br/portal/index.php?option=com content\&view=article\&id=55 $\underline{69}$

Dernis, H., Dosso, M., Hervás, F., Millot, V., Squicciarini, M., \& Vezzani, A. (2015). World corporate top R\&D investors: Innovation and IP bundles (No. JRC94932). Joint Research Centre (Seville site).

Donoso, J. F. (2017). A simple index of innovation with complexity. Journal of Informetrics, 11, 1-17. https://doi.org/10.1016/j.joi.2016.10.009

Forero-Pineda, C. (2006). The impact of stronger intellectual property rights on science and technology in developing countries. Research Policy, 35, 808-824. https://doi.org/10.1016/j.respol.2006.04.003

Hudson, J., \& Minea, A., (2013). Innovation, Intellectual Property Rights, and Economic Development: A Unified Empirical Investigation. World Development, 46, 66-78. https://doi.org/10.1016/j.worlddev.2013.01.023

International Chamber of Commerce. (2016). The Economic Impacts of Counterfeiting and Piracy (report prepared for BASCAP and INTA). ICC. Retrieved from https://cdn.iccwbo.org/content/uploads/sites/3/2017/02/ICC-BASCAP-Frontierreport-2016.pdf>.

Instituto Nacional de Propriedade Industrial. (INPI). (2009). Relatório de Gestão de 2009. Rio de Janeiro: Inpi/MDIC. Retrieved from <https://www.inpi.gov.br>.

Instituto Nacional de Propriedade Industrial (INPI). (2016). Boletim Mensal de Propriedade Industrial: Ranking dos Depositantes Residentes 2015 (Estatísticas Preliminares). Rio de Janeiro v.1, n. especial, p. 1-17, maio. Retrieved from http://www.inpi.gov.br/sobre/estatisticas/boletim-mensal>).

Instituto Nacional de Propriedade Industrial (INPI). (2017). Boletim Mensal de Propriedade Industrial: Estatísticas Preliminares. Rio de Janeiro v.2, n. 2, pp. 119. 
http://www.inpi.gov.br/sobre/estatisticas/arquivos/publicacoes/boletim fev2017.pdf>.

Jandhyala, S. (2015). International and domestic dynamics of intellectual property protection. Journal of World Business, 50(2), 284-293. https://doi.org/10.1016/j.jwb.2014.10.005

Jungmann, D., \& Bonetti E. (2010). A caminho da inovação: proteção e negócios com bens de propriedade intelectual: Guia para o empresário. Brasília: IEL.

Lei no 10.973, de 2 de dezembro de 2004. Dispõe sobre incentivos à inovação e à pesquisa científica e tecnológica no ambiente produtivo e dá outras providências. Diário Oficial da República Federativa do Brasil, Brasília, DF. Retrieved from http://www.planalto.gov.br/ccivil 03/ Ato2004-2006/2004/Lei/L10.973.htm .

Matias-Pereira, J. (2011). A gestão do sistema de proteção à propriedade intelectual no Brasil é consistente?. Independent Journal of Management \& Production, 2(2), 44-74. http://dx.doi.org/10.14807/ijmp.v2i2.24

Ministério da Ciência, Tecnologia e Inovação (MCTI). (2016). Estratégia Nacional de Ciência, Tecnologia e Inovação 2016-2019. Brasília: MCTI. Retrieved from http://www.mcti.gov.br/documents/10179/1712401/Estrat\%C3\%A9gia+Nacional+ de+Ci\%C3\%AAncia\%2C\%20Tecnologia+e+Inova\%C3\%A7\%C3\%A3o+20162019/0cfb61e1-1b84-4323-b136-8c3a5f2a4bb7.

Organisation for Economic Co-operation and Development (2014). Going for Growth. Country Note on Brazil. Organisation for Economic Co-operation and Development: Paris.

Papageorgiadis, N., Alexiou, C., \& Nellis, J. (2016). International licensing revisited: the role of copyright and trademark enforcement strength. European Journal of Innovation Management, 19(2), 261-275. https://doi.org/10.1108/EJIM-03-20150014

Russo, S. L. (Org.). n/a et al. (2017). Propriedade Intelectual, Tecnologias e Empreendedorismo. Aracaju: Associação Acadêmica de Propriedade Intelectual.

Stal, E., \& Fujino, A. (2016). The evolution of universities' relations with the business sector in Brazil: What national publications between 1980 and 2012 reveal. Revista de Administração, 51(1), 72-86. http://dx.doi.org/10.5700/rausp1224

Tanaka, H., \& Iwaisako, T. (2014). Intellectual property rights and foreign direct investment: A welfare analysis. European Economic Review, 67, 107-124. https://doi.org/10.1016/j.euroecorev.2014.01.013

Thursby, J., \& Thursby, M. (2011). Has the Bayh-Dole act compromised basic research? Research Policy, 40(8), 1077-1083. https://doi.org/10.1016/j.respol.2011.05.009 
Santos, M. E. R. (Org.). n/a et al. (2009). Transferência de tecnologia: estratégias para a estruturação e gestão de Núcleos de Inovação Tecnológica. Campinas: Komedi, 21-37.

United Nations Educational, Scientific and Cultural Organization. (2015). UNESCO Science Report: Towards $2030 . \quad$ Unesco. Retrieved from http://unesdoc.unesco.org/images/0023/002354/235406e.pdf.

United States Patent and Trademark Office. (2015). Retrieved from

$<$ https://www.uspto.gov/patents-application-process/search-patents 